\title{
Causes of Underinsurance against Natural Disasters
}

\author{
by Howard Kunreuther*
}

\section{Introduction}

Why do relatively few individuals voluntarily purchase coverage against natural disasters? This question has important implications for public policy for two principal reasons :

1. Uninsured victims of natural disasters may incur severe financial losses which will affect their future well-being. After a disaster the common lament is, "I wish that I had purchased insurance."

2. General taxpayers may be forced to help share the costs of recovery in the form of government grants and low-interest loans to uninsured disaster victims. This raises the question as to whether disasters are primarily a public or private responsibility.

This paper addresses the causes of underinsurance against natural disasters in the context of a broader conceptual framework which highlights the importance of linking descriptive analysis with prescriptive recommendations. At a descriptive level there is a need to specify the behavior of individuals firms and government agencies associated with the provision of natural disaster insurance and disaster relief. Prescriptively, there is a need to develop and evaluate alternative strategies for dealing with the problem of underinsurance. However, without an understanding of how different actors and stakeholders currently behave and are affected by institutional and legal arrangements, it is imprudent to make any policy statements as to what strategies should be followed in the future.

The problem confronting the policymaker is typical of what can be termed the "low probability-severe consequence" syndrome ; few individuals voluntarily protect themselves against the potential losses from a natural disaster. After the event they demand funds to help them recover. If the disaster is catastrophic, governments have responded with special relief measures.

Consider some empirical evidence from the United States. The San Francisco earthquake of 1971 caused property damage of approximately $\$ 500$ million, of which only $\$ 32$ million was covered by insurance. As a result, the Small Business Administration

* Department of Decision Sciences, The Wharton School, University of Pennsylvania, Philadelphia, PA 19104. 
disaster loan program provided over $\$ 257$ million in aid to homes and businesses; $\$ 165$ million was in the form of forgiveness grants and the remaining amounts were in the form of 3 percent loans. Hence the general taxpayer assumed much of the financial burden of recovery.

Tropical Storm Agnes, which wreaked havoc on many areas of the northeastern part of the United States in June of 1972, caused over \$2 billion in flood damage, making Agnes the costliest natural disaster in the nation's history. Even though a number of the communities in the affected region qualified for the federal government's subsidized national flood insurance, very few people had acquired coverage prior to the storm. In fact, only 1,580 claims, totalling \$5 million, were paid under the National Flood Insurance Program. Residents and businesses suffering damage obtained forgiveness grants up to the first $\$ 5,000$ of the loss, which totalled $\$ 540$ million. Many received loans (totalling an additional $\$ 660$ million) at an attractive 1 percent annual rate to cover the remaining portion of their losses. The same grants and loan provisions were offered to both high and low income residents so that equity and distributional considerations were not part of the design of the program (Kunreuther [1973]) ${ }^{1}$.

\section{A conceptual framework}

Figure 1 depicts a broad conceptual framework for integrating the descriptive and prescriptive phases. The problem under consideration is dealing with the problem of underinsurance against natural disasters. The descriptive phase has two components : the institutional arrangements and the decision processes. By institutional arrangements (Box 1) we mean the current organizational structure, legal restrictions and flow of information between the different interested parties who are affected by disaster insurance. Each stakeholder has his or her own goals and objectives as to how to deal with the problem of underinsurance against disasters. Furthermore, the power of these groups may differ, depending upon their legal rights and formal responsibilities under existing disaster insurance arrangements.

A central element of the framework, and one which has been frequently neglected in policy analysis studies, is the decision process of the different interested parties (Box 2). What information was available to each stakeholder and how were these data used? Empirical evidence emerging from field surveys and controlled laboratory experiments reveals that individuals collect limited information and exhibit systematic biases in processing data. An understanding of these limitations is an important basis for policy.

The prescriptive phase, which consists of the formulation and evaluation of different strategies, depends upon our understanding of the current institutional arrangements and decision processes of the different actors. Consider the following two scenarios as alternative explanations of the lack of interest by individuals in purchasing disaster insurance.

1 The only victims who may have been discouraged or prohibited from taking out large loans were the very low-income residents who "did not have the ability to repay." There are no published data as to how many (if any) rejections were made on this basis after Tropical Storm Agnes. 
Descriptive Phase

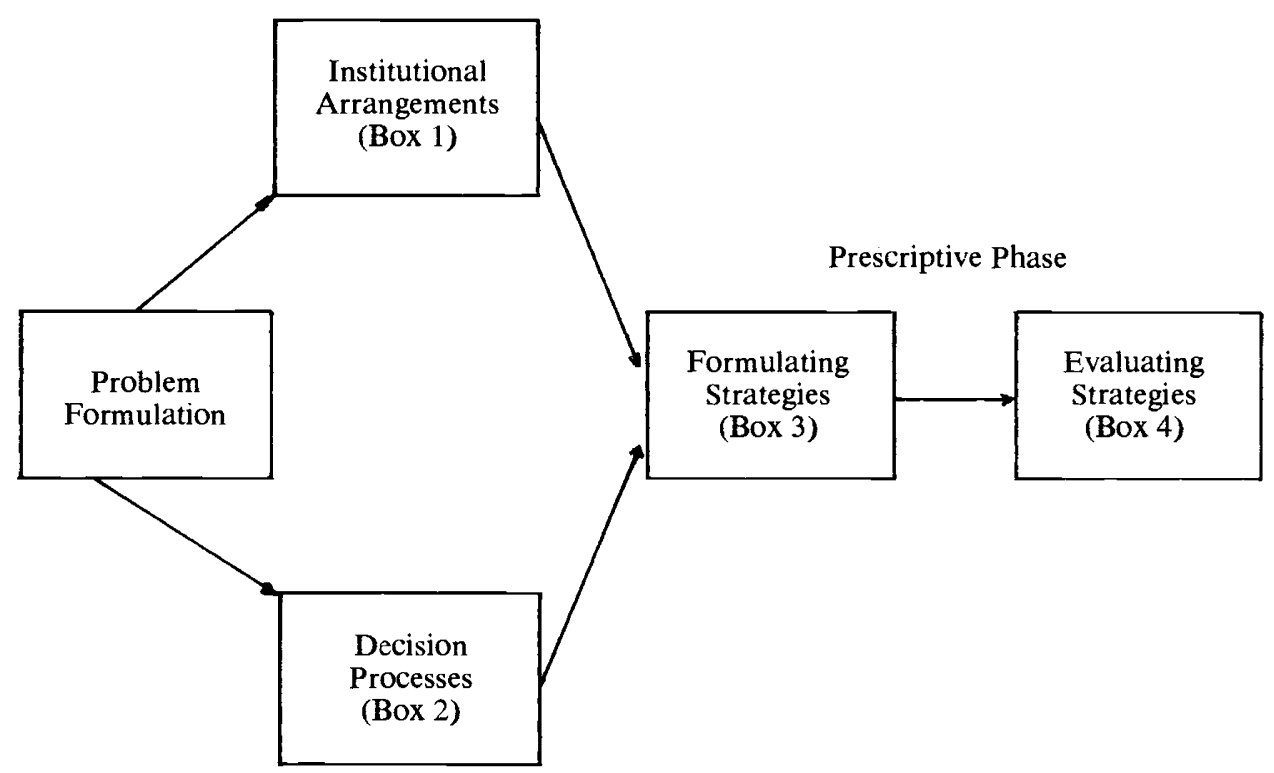

(1) Individuals may underestimate the losses and/or probability of a disaster so that the benefits of insurance protection appear unattractive relative to the cost of the policy. Furthermore, the individual may overestimate the premium on a policy, further discouraging him or her from purchasing insurance.

(2) Individuals assume the probability of a disaster is sufficiently low, that it is not worth even considering the potential loss. If this is the case, insurance will not even be considered as a viable option.

The formulation of strategies (Box 3) depends on the nature of the scenario. If Scenario 1 was a description of reality, then one possible strategy would be to provide correct information on the probability and consequences of a disaster as well as the costs of coverage. These data may convince some of the residents in disaster-prone areas to purchase coverage.

If Scenario 2 described reality, then either information on the chances of a natural disaster must be presented in a way that individuals pay attention to its consequences or some form of regulatory action may have to be imposed, such as having financial institutions require disaster insurance as a condition for a mortgage.

Finally, as seen from Figure 1, there is the evaluation of strategies (Box 4). We need to explicitly determine how alternative programs involving insurance are likely to affect 
different stakeholders. For example, if the government provided some form of reinsurance to cover the insurance industry against catastrophic losses, this would presumably reduce premiums and be an incentive for agents and companies to market coverage more aggressively. On the other hand, there may be a reluctance on the part of some stakeholders to having this type of government involvement in insurance. We need to know the impact of proposed programs on:

(1) residents of disaster-prone areas ;

(2) general taxpayers ;

(3) the insurance sector;

(4) banks and financial institutions;

(5) real estate agents ;

(6) the public sector.

One of the issues in evaluating different strategies is what importance weights should be given to different groups. For example, if there is a substantial concern with the plight of residents in hazard-prone areas relative to the general taxpayer, then programs which involve premium subsidies or special relief to disaster victims will be deemed more attractive than actuarially fair insurance or disaster loans at a market rate of interest. Another critical issue is what role state, local or federal governmental agencies should play in dealing with misperceptions that individuals may have on the hazard.

Given our increased understanding of the imperfect information and simplified rules that people use in making decisions, the issue of when one regulates and when one does not has to be addressed directly by policy-makers in formulating alternative strategies. It also has philosophical and ethical overtones regarding the troublesome question: "When is it appropriate to protect individuals from themselves?" The answer to this query will vary between countries due to different cultural and social norms.

A closer look at each of the eleinents of the conceptual framework should provide insights into the importance of descriptive and prescriptive analyses in dealing with the problem of underinsuring against natural hazards.

\section{Institutional arrangements (Box 1)}

In order to understand the degree of underinsurance against natural disasters, we have to clarify the roles of the different stakeholders who are associated with the insurance market. The following general questions are relevant in dealing with the institutional arrangements in a particular country :

- What is the attitude of the general taxpayer toward banks and financial institutions with respect to requiring disaster insurance as a condition for a mortgage ?

- How actively do insurance companies market different types of voluntary disaster insurance coverage?

- What is the role of reinsurance companies toward providing protection to insurance firms against possible catastrophic losses from a severe disaster?

- What is the role of the government in offering coverage or providing information regarding the hazard itself and available protection against disasters ? 
- How do residents feel about the desirability of voluntarily purchasing disaster insurance or actually having insurance required?

Each country will have a different set of institutional arrangements between those providing protection and those who may need it. Hence, the answers to the above questions are likely to vary across nations. For this reason we cannot even address the degree of underinsurance and/or its causes until we understand how different countries deal with the problems of natural disasters.

Consider a few examples :

- In Great Britain all natural disasters are included in a standard homeowners policy which is required by banks as a condition for a mortgage. Hence, the degree of underinsurance will be either due to those mortgagees who have less than full protection or those residents who own their property clear and have decided to let their insurance lapse.

- In July 1982, the French Parliament passed a new law which compels private insurance companies to include all natural disasters as part of their standard fire insurance policy. Since fire insurance is optional in France, only those who have purchased a policy will be eligible for disaster coverage (Charbonnier [1983]).

- In the United States flood and earthquake coverage are not part of a homeowners policy, so they must be purchased separately by residents of hazard-prone areas.

- In New Zealand most natural hazards are included under a government program of insurance under the Earthquake and War Damage Fund.

These four cases suggest that we can only address the degree of underinsurance and its causes after we first understand how different countries treat the public and private responsibilities of protection.

To provide a context which can serve as a basis for comparison with other countries, the questions on the previous page will be examined in the context of institutional arrangements in the United States.

Banks and financial institutions in the United States normally require individuals to purchase a standard homeowners policy as a condition for a mortgage. Thus, most people are protected against fire damage and other natural hazards, such as tornadoes, windstorms, hail and lightning. The amount of protection depends upon their policy limits in relation to the current value of their property and contents.

Earthquake insurance is marketed privately by American insurance companies and is available throughout the country. Approximately three-fourths of all policies are purchased in California, where coverage has been available to residents since 1916 . Premiums for wood-frame homes in California, which comprise almost all residential structures in the state, average $\$ 2$ per $\$ 1,000$ coverage (with a 5 percent deductible). Coverage can be written as an endorsement to a standard homeowners policy.

Today less than 5 percent of all homeowners in California are protected against earthquake damage. In contrast to the lack of interest by consumers in coverage, most large business firms protect themselves against earthquake damage. Rates are determined by the type of structure and its value. Normally the firm and the industry share coverage for a firm's property, with the firm self-insuring small losses through a high deductible (Western States Seismic Policy Council [undated]) 
Today insurance companies do not actively market earthquake coverage because they fear that there is not enough private reinsurance capacity to absorb the probable maximum loss that would result from a damaging quake in a populated area. Currently the National Association of Insurance Commissioners (NAIC) and the National Committee on Property Insurance (NCPI) are undertaking an earthquake insurance "Data Call" whereby all licensed insurers and reinsurers in California (approximately 417 companies) are required to provide information on the number and amount of earthquake coverage on dwellings and homeowners policies. These data will help determine whether the private sector has the ability to provide the required capacity to protect against a probable maximum loss.

The National Flood Insurance Program, which was initiated in 1968 , is the first positive step taken by the federal government to induce individuals to protect themselves against flood disasters. The program encourages homeowners and businesses through federal rate subsidies to purchase coverage. At the same time the sale of this insurance by private insurance companies and other agents is restricted to communities who agree to adopt permanent land-use and control measures in special flood-hazard areas. Property owners residing in the community at the time it enters the flood program are able to buy coverage at highly subsidized rates. After flood insurance rate maps have been determined for a given area, premiums reflecting the actual risk are charged on new construction.

Today all flood insurance is publicly underwritten by the Federal Emergency Management Agency (FEMA) although private insurance agents, brokers and adjustment organizations are involved in the marketing of coverage and the settlement of claims. ${ }^{2}$ Given the lack of interest by homeowners in voluntary coverage, Congress in 1973 required all homeowners on the flood plain applying for a federally-insured mortgage to purchase this coverage if their communities were enrolled in the program. Thus, by invoking sanctions on residents in flood-prone areas, the program has grown markedly in recent years.

In 1981 FEMA raised flood insurance rates with the goal of making the program self-sustaining and actuarially sound by 1988 . The result was a 7-1/2 percent decrease in policies written between December 1980 and November 1982. In addition to the rate increase, several other factors caused this decline: the smaller number of floods and property damage during this period, the general economic recession in the United States, and the recent decline in the housing market (U. S. General Accounting Office [1983]).

\section{Decision processes (Box 2)}

We now turn to the decision processes of the different interested parties who are affected by the problem. There is substantial knowledge regarding the type of information collected and utilized by some stakeholders. Considerably less is known with respect to others.

\section{Residents of disaster-prone areas}

Field surveys of homeowners in hazard-prone areas and controlled laboratory experiments have shed light on the decision processes associated with the purchase of

${ }^{2}$ For a more detailed discussion of the National Flood Insurance Program in the context of the overall management of flood risks, see Baram and Miyares [1982]. 
disaster insurance. ${ }^{3}$ The field survey involved face-to-face interviews with 2,055 homeowners residing in 43 areas throughout the United States subject to coastal and riverine flooding, and 1,006 homeowners living in 18 earthquake-prone areas of California. Half the respondents had purchased flood or earthquake insurance, the other half had not. The controlled laboratory experiments undertaken by Paul Slovic, Baruch Fischhoff, and Sarah Lichtenstein at Decision Research, investigated the causal relationships between variables entering into the insurance decision. A few of the key findings from this study which relate to individual decision processes are now summarized.

Analyses of the data reveal that most individuals do not engage in a detailed analysis of the costs and benefits associated with the purchase of insurance. Rather, they rely on past experience as a guide to action, choosing to protect themselves with insurance if they feel the hazard is a serious problem.

One explanation for this behavior has been offered by Tversky and Kahneman [1973] on the basis of a series of controlled laboratory experiments. The two psychologists hypothesize that individuals utilize a heuristic which they call availability, whereby the probability of an event is judged by the ease with which such instances are retrieved from memory. Past experience may be necessary to raise the probability to a level where a person feels that it is a problem worthy of attention. The following comments from homeowners in the flood plain illustrate this process.

"You ask me why I didn't have insurance before the June 1972 flood," said one homeowner in Norristown, Pennsylvania. "We had the flood in September of '71 and I had two feet of water in my basement. And I felt this I can tolerate and this is probably as high as it will ever get." To his chagrin, this man suffered severe property damage in 1972. Only then did he decide that he needed insurance. Another uninsured flood victim said that his rationale was that "the $\$ 60$ in premiums they could use for something else. But now they don't care if the figure was $\$ 600$. They're going to take insurance because they've been through it twice and they've learned a lesson from it" (Kunreuther et al. [1978]). Similar behavior was observed in quake-prone areas of California. Following the Santa Barbara earthquake of 1978 , insurance agents noted a sharp increase in demand for coverage (MacDougall [1981]).

Another important factor in influencing the purchase of a policy appears to be knowing someone who has purchased coverage or discussing insurance with a friend, neighbor or relative. The following example graphically illustrates this point : In a pretest of the earthquake questionnaire in San Francisco, a homeowner responded to one of the questions by saying that he did not have earthquake insurance. A friend of his listening to the interview commented that he had, himself, purchased such insurance a few years before. The respondent was most surprised and asked his friend about the availability of earthquake coverage and how much it cost. "I'm going to have to look into earthquake insurance myself," he added.

With respect to the type of information collected on coverage, most uninsured homeowners were aware that flood and earthquake coverage existed, but over $50 \%$ did not know that they could buy coverage. The vast majority of those who were aware had

\footnotetext{
${ }^{3}$ For more details on the survey and laboratory experiments, see Kunreuther et al. [1978] and Slovic et al. [1977].
} 
no reliable knowledge of the policy. Homeowners were also asked the maximum amount that they would be willing to pay for coverage. Over one-third of the uninsured residents of earthquake-prone areas were willing to pay more than the current rate for coverage, as were 27 percent of the uninsured in flood-prone areas. Had these nonpolicyholders been aware of the actual premium, they should have been interested in buying coverage.

Turning to the hazard itself, the field survey indicates that almost 90 percent of the homeowners were able to provide figures on their anticipated losses from a severe flood or earthquake, although there was a significant overestimation bias. There were also misestimates of the probability of severe disasters occurring. Some people thought the probability of a disaster hitting them was quite high - 1 chance in 10 - yet they said they had purchased no insurance. Others believed the chance of a disaster affecting them was almost nil - 1 in 100,000 - yet they had purchased coverage. It seems evident that a number of individuals participating in the field survey did not understand the concept of probability.

It is tempting to attribute this casual attitude about the risks of natural hazards and protective activities to homeowners' beliefs that the federal government will bail them out in a crisis. But the field survey data revealed that the majority of uninsured residents anticipate no aid from the government in the event of a disaster. Most of these people were aware that the SBA provides recovery funds to victims, but they had little knowledge of the loan terms or whether they could receive forgiveness grants. On the basis of these results, one can conclude that most homeowners in hazard-prone areas have not considered how they would recover should they suffer flood or earthquake damage. Instead they treat such events as being so unlikely that they ignore the consequences altogether.

One area for fruitful research is to understand more fully why individuals do not purchase insurance. Roberts [1982] contends that the decision on whether or not to purchase insurance depends on other factors besides wealth effects. In this connection, Akerlof and Dickens [1982] claim that persons do not think about buying coverage because by taking such a step they are implicitly acknowledging that they are in a hazard-prone area. They prefer to avoid confronting this issue by believing that they are living in a safe area, thus avoiding the unpleasant feelings of constant fear.

\section{Firms and businesses}

We have much less information about the decision processes of these stakeholders in hazard-prone areas. As pointed out earlier, most commercial buildings are insured against earthquakes, which suggests that firms have a much greater concern with the hazard that do consumers. One reason for this contrast may be the different emphases placed on the critical dimensions of the problem : consumers appear to focus on the low probability of the event and do not pay attention to the consequences. Risk managers in firms, on the other hand, are most concerned about the potential loss and do not focus on the probability of its occurrence. They see insurance as an attractive buy relative to the penalty they would suffer after a disaster, should their firm be unprotected (Borkan and Kunreuther [1979]).

\section{Insurance industry}

Until now, there has not been an active interest by insurance firms or their agents in encouraging their clients to purchase earthquake or flood insurance. Coverage is viewed 
as a special service to customers holding other policies with the company rather than as a profit-making operation. Nevertheless, efforts were made following the San Fernando earthquake of 1971 to make people aware of the availability of this type of protection. For example, the Insurance Company of North America placed newspaper ads in the major dailies, advertised on TV and provided California agents with special brochures and announcements that they could mail to their customers. The month after this campaign began they sold only 61 policies in the entire state and then sales dropped off to an average of 7 per month during the next 7 months (Syfert [1972]). The Hartford Insurance group and Kemper Companies ran similar campaigns to market earthquake insurance. Their efforts also bore little fruit.

A study of the National Flood Insurance Program in New York State found that many agents had little interest in the program because they felt that the volume of business would be low and that they would be unlikely to pick up new clients as a result of the contacts made (Preston, Moore and Cornick [1975]).

\section{Banks and financial institutions}

It is not clear from existing literature as to how banks and financial institutions in the U.S. feel about requiring flood or earthquake coverage as a condition for a mortgage. If banks were to mandate coverage on new dwellings, this insurance would provide a substitute for liberal disaster relief following a catastrophic disaster. On the other hand, there is no empirical evidence suggesting that people would make different location decisions if they were now forced to take out coverage. The best chance of achieving this sensitivity to the hazard would be for rates to reflect the risk of residing in specific areas. However, given the large monetary transaction in purchasing a house and other factors influencing location, the premium differentials are likely to have a small impact on most buyers' actions.

Residents in hazard-prone areas and the general taxpayer appear to be receptive to some form of insurance requirement as a condition for a mortgage or loan on structures in hazard-prone areas. Over half of the respondents in the field survey felt that it would be fair for banks and financial institutions to impose this condition. Similar findings were reported by Cummins et al [1974] in a study of consumer attitudes toward insurance. When asked the question, "Would you favor or oppose a law which required all people who live in flood and earthquake zones to have flood and earthquake insurance? ", almost 60 percent of the respondents replied in favor of such a regulation and only 30 percent were opposed to it. The rest did not have an opinion.

One reason that banks and financial institutions would want to require insurance is that they fear a run on their deposits and liquidity position in the wake of a disaster. Steindl and Weinrobe [in press] have looked at deposit data of seven individual savings and loan associations and eight commercial banks in four disasters (the Rapid City flood, Wilkes-Barre flood from Tropical Storm Agnes, Xenia tornado and Johnstown flood), and found no evidence of any runs during the month following the disaster. Insurance did appear to make a difference, however. In Xenia, where residents were covered against tornado damage by homeowners coverage, new net savings in the two savings and loan associations studied in the post-disaster month were between six and seven times higher than normal, presumably because of a rapid settlement of private insurance claims. 


\section{Real estate agents}

Real estate agents can play a critical role in providing potential buyers with key information about the characteristics of their neighborhoods and the type of hazards that they may face. These agents seem to be doing little or nothing to discourage sales in areas susceptible to natural disasters. They are either unaware of the risks associated with portions of the community, or downplay the significance of such warnings as fault zoning (Palm [1981]). Results of our field survey confirm this finding. Over 40 percent of the residents interviewed did not believe that there was an earthquake problem in their area at the time they bought their house. Furthermore, 30 percent of the homeowners did not have any idea how far their house was from a fault. In a group focus depth interview, one Bakersfield resident summed up the situation very succinctly: When you go out to buy a piece of property, the real estate agent doesn't say: "I want you to understand that there's a fault running right down the middle of this thing." You buy the house, and six years later somebody tells you you're sitting on top of a fault (Kunreuther et al. [1978]).

\section{Public sector}

Various federal, state and local agencies have key roles to play by combining insurance with other policy tools in mitigating disaster losses and aiding the recovery process. Currently, the principal roles of state and local agencies are to provide residents and businesses with information on both the hazard itself and available tools for reducing potential losses. The task of educating public officials about the disaster risks in their areas is enormous because of the high turnover in these positions, as well as the low salience of the hazard when contrasted with other issues which demand their attention (Wright et al. [1979]).

\section{Formulating strategies (Box 3)}

The performance of different insurance programs will be directly related to the existing institutional arrangements and the decision processes of the different stakeholders. It is thus necessary for us to understand the type of information that is likely to be disseminated, collected and processed by the different groups who interact with each other. Furthermore, it is important to specify in advance the objective of a particular program.

If policymakers feel that it is the responsibility of residents in hazard-prone areas to protect themselves against the risks of natural disasters, every effort should be made to provide residents with accurate information on the hazard and alternative mitigation measures. Furthermore, the government should then not come to the rescue with special relief. On the other hand, if there is concern that the government will succumb to political pressures by providing generous aid to all uninsured victims, then stronger measures may be required. Below we briefly discuss a set of alternatives which could be considered.

\section{Voluntary insurance}

Based on how information is currently presented to consumers on the hazard, there is likely to be limited interest in coverage until after the next severe disaster even if the insurance premium is subsidized. Should the government provide generous relief there 
will be no financial incentive for homeowners to buy coverage. Businesses, on the other hand, are likely to be well-protected against the financial consequences of a severe disaster because they are primarily concerned with the potential catastrophic loss to them.

\section{Required insurance}

Unless the insurance industry determines that it has the available resources to absorb the consequences of a probable maximum loss, it is likely to be opposed to mandatory insurance unless the government provides some type of catastrophic loss reinsurance. Under current federal income tax provisions, premiums placed in a reserve fund for catastrophies are treated like excess profits, and hence taxed at a rate of 50 percent.

With respect to earthquake coverage, Brown [1982] has concluded that the United States government cannot require that existing and future residential homeowners policies include an earthquake clause the reason that such a proposal would be unconstitutional is that the world-wide financial capacity of the insurance and reinsurance industry is far less than would be needed. On the other hand, there are other countries such as Great Britain which have required disaster insurance as a condition for a mortgage.

\section{Comprehensive catastrophic insurance}

Rather than dealing with earthquake insurance as a separate policy, proposals have been made for incorporating this coverage into a catastrophic insurance system covering all natural hazards (Kunreuther [1968] ; Anderson [1975, 1976]). The private sector would promote, distribute and sell the policies, servicing policyholders and adjusting claims ; the federal government would establish the essential components of the system and provide reinsurance to the private companies in case of a catastrophic loss.

On the surface this concept appears to be attractive due to its simplicity, but Hall [1975] indicates that it raises a set of questions which merit further discussion. Specifically, such coverage would undoubtedly require some form of reinsurance against losses from a catastrophic disaster. This would mean that the government would be injecting itself into areas of property insurance which in the United States have traditionally been in the private domain. In the past, the industry has resisted such encroachment unless it is absolutely essential.

There are lessons from other countries here. Spain has developed compulsory protection against catastrophic disaster losses from natural disasters or riots to property, persons and farming, fishing and forestry. The definition of a "catastrophe" and reimbursement of losses are determined by a central government committee called the Consortium. The catastrophe insurance plan is supported by compulsory surcharges on the premiums of basic policies covering the individuals or their property. Presumably the Consortium may borrow from the Bank of Spain if loss payments exceed the available funds (Greene [1972]).

\section{Creating concern for the hazard and insurance}

Results of the field survey and controlled laboratory experiments on insurance suggest that persons only will consider protecting themselves against low probability, high consequence events if they are convinced that the chance of occurrence is, in fact, high enough to warrant attention. One way to increase concern with the hazard may be to 
present information on the probability of a future disaster on a different time interval than the traditional one year period. Thus, in describing the chances of a flood or quake which has an annual probability of .01 , one could note that for someone living in a house for 25 years, the chance of suffering damage from such a disaster at least once during this period will be .22. By stretching the time interval in this way the person may then view the probability of loss to be high enough to warrant interest in insurance.

The insurance agent can also trigger interest in coverage by stimulating people's awareness of the hazard and providing accurate information on the availability and terms of a policy. Since most individuals appear to treat insurance as an investment rather than a protective mechanism, one of the principal functions of the agent should be to educate his clients that the greatest return on their insurance is not to have any return at all. Such a process of education requires time on the part of the agent, which he may not be willing to give with commissions at their current level.

\section{Insurance as a coordinating mechanism}

Insurance is a logical mechanism for providing individuals with economic incentives to adopt other measures such as making their structures more earthquake-resistant or flood-proof. Pamphlets could be sent to all homeowners indicating the possible measures they could adopt and offering a reduction in annual premiums should they reduce the risk of future damage. In addition, the government might consider providing homes and businesses with low-interest improvement loans to encourage them to undertake such adjustments. If the benefits of the protective measures exceed the costs, the reduction in premiums may more than offset the loan charges.

As pointed out above, there is no guarantee that economic incentives will spur homeowners to adopt protective measures. For this reason, it may be necessary to supplement these incentive systems with land-use controls and building codes such as has been done in the National Flood Insurance Program. In developing these regulations there is a need for accurate information on the hazard and its risk as well as the potential costs and benefits of the rules to the affected individuals and to society.

Even with these combined mitigation and recover measures, a disaster relief program may be desirable for assisting special groups such as low income individuals or elderly residents who may be uninsured either because they could not afford coverage or because they did not possess sufficient information on the availability and terms of a policy. Similarly, after a catastrophic disaster, there may be a need to offer special relief to victims to cover the uninsured portion of their loss. If the government deems such measures important, then it would be wise to pass legislation prior to a catastrophe rather than having to react to each situation with a new disaster bill.

\section{Evaluating strategies (Box 4)}

As pointed out in the introduction, any disaster insurance program impacts on a number of different stakeholders. Figure 2 illustrates the interaction between the types of strategies discussed above (the rows) and the six different stakeholders discussed in the previous section (the columns). The cells in the matrix are used to indicate the costs and 
Figure 2: Strategy - Stakeholder matrix

\begin{tabular}{|c|c|c|c|c|c|c|}
\hline Stakeholders & $\begin{array}{c}\text { Residents } \\
\text { of } \\
\text { Quake } \\
\text { Prone } \\
\text { Areas }\end{array}$ & $\begin{array}{l}\text { General } \\
\text { Taxpayer }\end{array}$ & $\begin{array}{l}\text { Insurance } \\
\text { Sector }\end{array}$ & $\begin{array}{c}\text { Banks } \\
\text { and } \\
\text { Financial } \\
\text { Institutions }\end{array}$ & $\begin{array}{c}\text { Real } \\
\text { Estate } \\
\text { Agents }\end{array}$ & $\begin{array}{l}\text { Public } \\
\text { Sector }\end{array}$ \\
\hline \multicolumn{7}{|l|}{ A. Voluntary Earthquake Insurance } \\
\hline \multicolumn{7}{|l|}{ B. Required Earthquake Insurance } \\
\hline \multicolumn{7}{|l|}{ C. Comprehensive Catastrophic Insurance } \\
\hline \multicolumn{7}{|l|}{ D. Create Concern for the Hazard } \\
\hline \multicolumn{7}{|l|}{ E. Insurance as a Coordinating Mechanism } \\
\hline F. Other Strategies & & & & & & \\
\hline
\end{tabular}

benefits of any strategy to the specific stakeholder. For example, a strategy of voluntary insurance involves costs to homeowners and businesses in the form of premiums, and benefits in the form of claims ; there are costs to the general taxpayer to the extent that rates are subsidized or liberal disaster relief is provided. Such a program would also impact on the insurance industry, banks and financial institutions, real estate agents and the public sector. Some of these changes could be quantified while others may be of a qualitative nature (e.g., better appreciation of the risks) which may eventually have quantitative significance (e.g., adopting protective measures).

The challenge in developing a meaningful disaster insurance program is to evaluate the different cells in the matrix and to utilize criteria for selecting between them. The relative merits of alternative strategies are reflected in two types of considerations.

First, there are resource allocation costs. These are likely to be incurred if homeowners and businesses locate in a disaster-prone region with misperceptions about the potential consequences from future disasters and the ways that they can protect themselves. The recent empirical evidence on natural hazards suggests that individuals do just that : many newcomers are unaware of the potential dangers they face and are not given much helpful information from knowledgeable sources such as real estate brokers or homebuilders. Once they settle in an area, they tend to assume that disasters to them will not occur during their lifetimes. In evaluating the impact on resource allocation of alternative programs such as voluntary or required insurance, land-use regulations and building codes, it is important to have a better understanding as to how individuals collect and process information.

Second, there are distributional considerations. This criterion represents the relative financial burden of a disaster to the victims and the rest of society. Governmental policies imply some value judgment as to what subsidies will be paid by the general taxpayer and how much by the residents of hazard-prone areas.

To evaluate the distributional impact of alternative programs, it is useful to understand the decision processes of individuals after a disaster. For example, there is evidence that many victims do not utilize the federal loan program to the extent possible. Some families may have had negative feelings toward incurring large debts, while others 
may have had their loan size limited by the SBA because the agency felt that these people could not afford to repay the loan. Whatever the reason, this self-reliance has resulted in many victims not recovering completely from the disaster because they were uninsured. Furthermore, those victims who availed themselves of generous SBA loans were then saddled with large debts for long periods of time. Vinso [1977] has shown that many elderly victims from Tropical Storm Agnes were financially crippled despite the generous SBA loan policy provided them after the disaster.

\section{Summary and conclusions}

This paper investigates the causes of underinsurance against natural disasters in the context of a conceptual framework which emphasizes integrating descriptive and prescriptive analysis. On the demand side empirical evidence reveals why homeowners have been reluctant to protect themselves against low probability-high consequence events, such as natural disasters, unless they are required to do so. On the supply side there are clear reasons why the insurance industry has been reluctant to actively promote this type of coverage.

From a prescriptive vantage point, Milliman [1982] has recently raised an important set of questions regarding the role of the public and private sectors in dealing with hazard mitigation programs, including insurance. He addresses the question of mitigation from the point of view of acceptable risk, arguing that we must evaluate the import and mix of different strategies to the various stakeholders in the community as well as examine their regional economic impacts.

In order to evaluate these alternative strategies, we need to understand the current insitutional arrangements and decision processes of the different stakeholders. This is a challenge for future studies jointly undertaken by social scientists and parties interested in the role of insurance as a tool for hazard mitigation.

\section{REFERENCES}

AKERLOFF, G., and DICKENS, W. [1982]: "The Economic Consequences of Cognitive Dissonance," American Economic Review 72: 307-319.

ANDERSON, D. [1975] : “ Development of the Principal Elements of a Comprehensive Catastrophe Insurance System," CPCU Annals, 28: 176-191.

ANDERSON, D. [1976] : “All Risks Rating Within A Catastrophe Insurance System," Journal of Risk and Insurance, $4: 629-651$.

BARAM, M., and MIYARES, R. [1982] : "Managing Flood Risk: Technical Uncertainty in the National Flood Insurance Program," Columbia Journal of Environmental Law, $7:$ 129-164.

BORKAN, B., and KUNREUTHER, H. [1979] : “Contingency Planning Against Low Probability Events," Best's Review, 80 : 106-112. 
BROWN, J. [1982] : “A Constitutional Analysis of Federally-Mandated Earthquake Insurance," (mimeo).

CHARBONNIER, J. [1983]: "Insuring Against Nature: How The French are Covering Natural Disasters," Business Insurance, March 28, 1983, p. 38.

CUMMINS, D., McGILL, D., WINKLEVOSS, H., and ZELTEN, R. [1974] : Consumer Attitudes Toward Auto and Homeowners Insurance, Philadelphia: The Wharton School, Department of Insurance.

GREENE, M. [1972] : "The Spanish Insurance Industry - An Analysis," Journal of Risk and Insurance, $38: 221-243$.

HALL, R. [1975] : “ Major Disaster Proposals Invite "Feds" into Areas Now Well Handled," The National Underwriter, March 21.

KUNREUTHER, H. [1968]: “The Case for Comprehensive Disaster Insurance," Journal of Law and Economics, 239-244.

KUNREUTHER, H. [1973]: Recovery from Natural Disasters: Insurance or Federal Aid, Washington, D.C., American Enterprise Institute for Public Policy Research.

KUNREUTHER, H., GINSBERG, R., Miller, L., SAGI, P., SLOVIC, P., BORKAN, B., and KATZ, N. [1978] : Disaster Insurance Protection: Public Policy Lessons, New York: John Wiley and $\mathrm{Co}$.

MacDOUGALL, A. [1981] : "Earthquake Insurance: Is it Worth It ?,” Los Angeles Times, March 8.

MILlimAN, J., [1982]: "Economic Issues in Formulating Policy for Earthquake Hazard Mitigation," prepared for NSF Workshop on Hazards Research, Policy Development and Implementation Incentives, University of Redlands, Redlands, CA, June 24-26, 1982.

PALM, R. [1981]: Real Estate Agents and Special Studies Disclosure, Institute of Behavioral Science, University of Colorado, Boulder, CO.

PRESTON, J. C., MOORE, D. E., and CORNICK, T. [1975] : "Community Response to the Flood Disaster Protection Act of I973", Ithaca: Cornell Community and Resource Development series, Bulletin I0.

ROBERTS, B. [1982]: "Conceptual Framework for Individual Choice for Earthquake Hazard Mitigation," College of Business Administration, University of South Carolina, Columbia, SC.

SLOVIC, P., FISCHHOFF, B., LICHTENSTEIN, S., CORRIGAN, B., and COMBS, B. [1977]: "Preference for Insuring Against Probable Small Losses : Implications of Risk and Insurance," Journal of Risk and Insurance, $44: 237-258$.

STEINDL, F., and WEINROBE, M. [in press] : "Natural Hazards and Deposit Behavior at Financial Institutions: A Note," Journal of Banking and Finance.

SYFERT, R. [1972] : “The Unwilling Market for Earthquake Insurance," Best's Review, 73 : 14-18.

TVERSKY, A., and KAHNEMANN, D. [1974] : "Judgment Under Uncertainty; Heuristics and Biases," Science, 185: 1124-1131.

U. S. GENERAL ACCOUNTING OFFICE [1983] : " The Effect of Premium Increases on Achieving the National Flood Insurance Program's Objectives," Washington, D.C.: U.S. General Accounting Office.

VINSO, J. [1977] : "Financial Implications of Natural Disasters : Some Preliminary Indications," Mass Emergencies, 2: 205-217.

WESTERN STATES SEISMIC POLICY COUNCIL [undated] : “ Earthquake Insurance,” (mimeo).

WRIGHT, J., ROSSI, P., and WRIGHT, S. [1979]: After the Clean-up: Long Range Effects of Natural Disasters, Beverly Hills, CA : Sage Publications. 